Politik Indonesia: Indonesian Political Science Review 1 (2) (2016) 105-119
Politik Indonesia
Indonesian Political Science Review
http://journal.unnes.ac.id/nju/index.php/JPI
Indonesia

\title{
Pengaruh Klientilisme terhadap Perilaku Pemilih Masyarakat Kecamatan Sukatani pada Pilkada Kabupaten Bekasi 2012
}

\author{
Ainur Rofieq $^{1 凶}$, Rahmat Nuryono ${ }^{1}$ \\ ${ }^{1}$ Universitas Islam “45” Bekasi, Indonesia
}

\section{Info Artikel Abstrak}

Sejarah Artikel:

Diterima 15 Maret 2016

Disetujui 15 Juni 2016

Dipublikasi 15 Juli 2016

Keywords:

Voting Behavior;

Clientelism; Bekasi

Region

\begin{abstract}
Penelitian ini dilatarbelakangi oleh keterpilihan Neneng Hasanah Yasin-Rohim Mintareja yang mengalahkan incumbent kepala daerah dan wakil kepala daerah pada Pilkada Kabupaten Bekasi tahun 2012. Dalam pemilihan kepala daerah tersebut terjadi dinamika perilaku pemilih masyarakat. Diduga terjadi praktik klientelisme dalam kemenangan Neneng Hasanah Yasin tersebut. Fokus penelitian ini adalah dengan melihat perilaku pemilih masyarakat di Kecamatan Sukatani yang memiliki karakteristik sebagai wilayah pertanian. Kecamatan Sukatani merupakan salah satu kecamatan yang menjadi basis kemenangan Neneng Hasanah Yasin. Sebagai alat analisis digunakan teori klientelisme. Metode penelitian yang digunakan adalah studi kuantitatif dengan kuesioner sebagai alat pengumpul data. Teknik analisa data menggunakan tabulasi silang. Jumlah sampel dalam penelitian ini sebanyak 100 orang dengan tingkat kepercayaan $95 \%$ dan margin of error $10 \%$. Hasil penelitian ini menunjukkan bahwa untuk beberapa indikator klientelisme tidak ada perbedaan perilaku memilih masyarakat Sukatani, seperti indikator popularitas orang tua kandidat, ajakan pejabat formal, ajakan pejabat informal, dan ajakan kelompok professional. Bahkan untuk indikator hutang budi tidak ada sama sekali. Sedangkan indikator yang memiliki perbedaan adalah pada ajakan tim sukses kandidat.
\end{abstract}

\begin{abstract}
This research is motivated by the election of Neneng Hasanah Yasin-Rohim Mintareja who defeated incumbent regional head and deputy head of the Bekasi area in the elections of 2012. The local elections showed a dynamic voter behavior of society. Clientelism practices allegedly occurred in the victory Neneng Hasanah Yasin. The focus of this study is to analyse voting behavior of people in the District Sukatani which has characteristics as agricultural area. Sukatani sub-district is one of the districts that form the basis for Neneng Hasanah Yasin victory. As an analytical tool, the used theory is clientelism. The method used is a quantitative study with a questionnaire as a data collector. Data analysis technique uses cross tabulation. The number of samples in this study is 100 people with a 95\% confidence level and a margin of error of $10 \%$. The results of this study indicates that for some indicators clientelism has no difference in voting behavior Sukatani society, such as indicators of the popularity the parents candidates, formal official invitation, informal official invitation, and professional groups invitation. Even for indicators of indebtedness does not exist at all. While indicators have differences on the invitation team is successful candidate.
\end{abstract}

(C) 2016 Universitas Negeri Semarang ISSN $2477-8060$

\footnotetext{
Alamat korespondensi:

Jl. Cut Meutia No. 83 Kec. Bekasi Timur, Kota Bekasi, Indonesia. Email: a_rofieq@yahoo.com
} 


\section{Pendahuluan}

Pemilihan umum kepala daerah dan wakil kepala daerah yang dilaksanakan secara langsung di Indonesia merupakan konsekuensi dari tuntutan demokrasi, agenda reformasi, dan desentralisasi. Setelah munculnya Undang-undang Nomor 32 Tahun 2004 tentang Pemerintahan Daerah, maka pelaksanaan pemilihan kepala daerah (Pilkada) dilakukan secara langsung dimana sebelum adanya undang-undang tersebut pelaksanaan pemilihan kepala daerah dilakukan oleh legislatif.

Penerimaan dan penolakan pemilih terhadap pasangan kandidat, dalam konteks kultur Indonesia, lebih banyak disebabkan oleh hubungan yang bersifat emosional dibandingkan rasional. Dalam pemilihan kepala daerah, penilaian terhadap kandidat tidak selamanya bersifat rasional. Masyarakat mungkin menilai kandidat bukan berdasarkan kapabilitas kandidat, tetapi lebih didasarkan pada latar belakang sosial ekonomi dan ketokohannya. Mereka tidak mendasarkan pilihan pada kemampuan intelektual, wawasan, penguasaan, pengalaman pribadi bahkan visi, misi, dan program calon. Pilihan didasarkan pada keturunan, latar belakang organisasi, garis ideologis, bahkan tampilan fisik (Asfar, 2005).

Terpilihnya Neneng Hasanah Yasin, sebagai Bupati Bekasi dalam Pilkada Kabupaten Bekasi 2012 merupakan sesuatu yang baru dalam sejarah masyarakat Bekasi. Kemenangan Neneng Hasanah Yasin menjadikannya sebagai kepala daerah perempuan pertama di Kabupaten Bekasi. Kabupaten Bekasi merupakan daerah dengan kultur masyarakat yang mengalami perubahan dari agraris perdesaan menjadi agraris industrialis dimana masih terdapat aturanaturan normatif baik di tingkat budaya, agama maupun hukum atau peraturan pemerintah yang masih belum mengakomodasi peran perempuan di wilayah publik. Pandangan stereotip mengenai peran perempuan masih mengandung nilai-nilai misoginis (Nuraina, dkk, 2008). Sebaliknya kekalahan pasangan Sa'duddin-Jamal Lulail Yunus serta pasangan Darip Mulyana-Jejen Sayuti sungguh di luar dugaan. Sa'duddin dan Darip Mulyana merupakan petahana Bupati dan Wakil Bupati Bekasi periode 2008-2012. Hal ini ditambah pula bahwa pasangan Sa'duddin dan Jamal Lulail Yunus adalah seorang ustadz.

Dalam hal proses penetapan Neneng Hasanah Yasin-Rohim Mintareja sebagai Bupati dan Wakil Bupati dilakukan melalui sebuah penetapan di Mahkamah Konstitusi. Gugatan hasil pelaksanaan pilkada diajukan oleh pasangan Sa'duddin-Jamal Lulail Yunus. Menurut penggugat, pasangan Neneng Hasanah Yasin-Rohim Mintareja melakukan kecurangan berupa adanya politik uang (money politics) di 15 kecamatan yang berlokasi di pinggiran Kabupaten Bekasi. ${ }^{39}$ Bahkan gugatan juga dikaitkan dengan peran orang tua Neneng Hasanah Yasin, Haji Yasin

39 http://www.republika.co.id/berita/regional/jabodetabe k/12/03/20/m16y3q-kalah-pilkada-dahsyay-saja-ajukangugatan-ke-mk, diakses tanggal 30 Mei 2012. 
yang merupakan seorang tokoh masyarakat Bekasi dan seringkali berperan aktif dalam mensukseskan pemilihan kepala desa di hampir seluruh wilayah Kabupaten Bekasi. Peranannya dianggap memanfaatkan struktur aparat desa untuk melakukan politik uang kepada para pemilih. $^{40}$ Meskipun pada akhirnya Mahkamah Konstitusi membatalkan gugatan pasangan Sa'duddin-Jamal Lulail Yunus, namun indikasi adanya politik uang dengan memanfaatkan mekanisme patronclient diduga terjadi pada Pilkada Kabupaten Bekasi Tahun 2012.

Pilkada Kabupaten Bekasi tahun 2012 merupakan pemilihan kepala daerah kali kedua setelah pemilihan pertama pada tahun 2007 pasca berlakunya Undang-Undang Nomor 32 Tahun 2004 tentang Pemerintahan Daerah. Dalam pilkada Kabupaten Bekasi tahun 2012 diikuti oleh tiga pasang calon bupati dan wakil bupati.

Apabila dibandingkan dengan pelaksanaan Pilkada Kabupaten Bekasi Tahun 2007, maka terjadi dinamika perilaku memilih pada Pilkada Kabupaten Bekasi Tahun 2012. Kecamatan Bojongmangu, Cabangbungin, Cikarang Pusat, Muaragembong, Sukatani, Sukawangi, dan Tarumajaya merupakan wilayah-wilayah yang mengalami dinamika dalam dua kali pelaksanaan pilkada. Menurut data KPU (2012) menunjukkan bahwa pada pelaksanaan Pilkada Kabupaten Bekasi Tahun

40 Dalam Bagian Alasan-alasan Pokok sebagai Dasar Keberatan Nomor 10 dan 11 Keputusan Mahkamah Konstitusi Nomor 9/PHPU.D-X/2012 tanggal 10 April 2012 .
2012 ketujuh kecamatan tersebut menjadi wilayah kemenangan pasangan Neneng Hasanah Yasin-Rohim Mintareja. Sedangkan pada Pilkada Kabupaten Bekasi Tahun 2007 menjadi basis kemenangan pasangan Sa'duddin-Darip Mulyana.

Kecamatan Sukatani merupakan salah satu dari tujuh kecamatan yang mengalami dinamika perilaku pemilih pada Pilkada Kabupaten Bekasi Tahun 2012. Dipilihnya kecamatan ini dikarenakan merupakan kecamatan yang diperuntukan untuk basis pertanian menurut pembagian wilayah pengembangan Kabupaten Bekasi. ${ }^{41}$ Kondisi

${ }^{41} \mathrm{http}$ //humaskabbekasi.wordpress.com/profil-kabupate n-bekasi/ diakses tanggal 18 Februari 2013. Pada tahun 1984 terdapat pembagian wilayah pembangunan yang ditetapkan dalam Perda Nomor 15/HK/OP.013.1/ VIII/1984 tentang Pola Dasar Pembangunan Daerah Tingkat II Bekasi. Tujuannya adalah agar pembangunan dapat berjalan dengan baik dengan tiga wilayah pembangunan. Perkembangan selanjutnya Kabupaten Bekasi dibagi menjadi empat wilayah prioritas berdasarkan Perda Nomor 4 Tahun 2003, terdiri dari:

a. Wilayah Pengembangan (WP) I merupakan kawasan pengembangan khusus Pantura, diatur secara khusus dalam Peraturan Daerah Kabupaten Bekasi Nomor 4 Tahun 2003. Karakter WP I adalah kota baru dengan sebutan Kota Baru Pantai Makmur seluas 25.028 Ha yang meliputi: Kecamatan Babelan, Tarumajaya, dan Muaragembong yang peruntukannya meliputi pengembangan permukiman, perdagangan dan jasa, pelabuhan (pergudangan/ terminal peti kemas), industri dan pariwisata.

b. Wilayah Pengembangan (WP) II adalah wilayah bagian timur Kabupaten Bekasi yang mempunyai karakter untuk memproduksi hasil-hasil pertanian seluas $47.020 \mathrm{Ha}$, meliputi: Kecamatan Cabangbungin, Sukawangi, Sukakarya, Tambun Utara, Tambelang, Pebayuran, Sukatani, Karang Bahagia dan Kedungwaringin.

c. Wilayah Pengembangan (WP) III adalah wilayah bagian tengah koridor timur barat Kabupaten Bekasi yang mempunyai karakter perkotaan dengan dominasi permukiman, perdagangan dan jasa, industri dan pemerintahan seluas $36.625 \mathrm{Ha}$, meliputi: Kecamatan Tambun Selatan, Cibitung, Cikarang Barat, Cikarang Timur, Cikarang Utara, Cikarang Selatan dan Cikarang Pusat.

d. Wilayah Pengembangan (WP) IV adalah wilayah bagian selatan Kabupaten Bekasi yang mempunyai 
ini sejalan dengan dugaan penelitian dimana mekanisme patron-client terjadi pada masyarakat perdesaan. Selain itu, di antara sembilan kecamatan yang terdapat di wilayah pengembangan tersebut, Kecamatan Sukatani memiliki dinamika pemilih yang paling tinggi. ${ }^{42}$

Kecenderungan seseorang untuk memberikan pilihan dalam pemilihan umum ditentukan oleh banyak faktor, seperti faktor sosiologis, psikologis, ekologis, dan pilihan rasional. Oleh karena itu, pertanyaan penelitian yang dapat diajukan adalah: "Bagaimana pengaruh klientelisme terhadap perilaku memilih masyarakat pada Pilkada Kabupaten Bekasi Tahun 2012?”

Berdasarkan permasalahan yang diteliti, maka tujuan penelitian adalah untuk mengetahui pengaruh faktor klientelisme terhadap perilaku memilih masyarakat pada Pilkada Kabupaten Bekasi Tahun 2012. Sedangkan hasil penelitian ini diharapkan dapat bermanfaat bagi penelitian serupa dan dapat memberi sumbangan bagi kajian studi ilmu politik di Indonesia, khususnya menguji teori klientelisme dalam konteks masyarakat lokal.

karakater untuk konservasi dan permukiman, pengembangan pertanian holtikultura serta pariwisata seluas 17.014 Ha, meliputi: Kecamatan Setu, Serang Baru, Cibarusah dan Bojongmangu.

42 Sembilan kecamatan di wilayah pengembangan berbasis pertanian adalah Kecamatan Cabangbungin, Sukakarya, Sukawangi, Tambun Utara, Tambelang, Pebayuran, Sukatani, Karang Bahagia, dan Kedungwaringin.

\section{Kajian Pustaka}

Perilaku Memilih

Studi mengenai pemilu dalam kajian ilmu politik dikenal dengan konsep "perilaku pemilih" (voting behavior). Perilaku pemilih terbentuk oleh suatu proses sosialisasi, yang dikenal dengan "sosialisasi politik" (political socialization). Sedangkan keikutsertaan dalam pemilu merupakan salah satu bentuk "partisipasi politik" (political participation). Menurut Berelson yang dikutip Indarti (2003), voting behavior adalah proses pembuatan keputusan dan faktor-faktor sosial yang mempengaruhi pola pemberian suara atau kesertaan dalam pemilihan.

Sedangkan menurut Ramlan Surbakti (1999), perilaku memilih dibedakan menjadi lima sesuai dengan pendekatan yang digunakan, yaitu struktural, sosiologis, ekologis, psikologi sosial, dan pilihan rasional. Hal yang sama dijelaskan oleh Dennis Kavanagh yang dikutip oleh Imawan (1995) sebagai berikut: (1) Structural Approach. Dalam pendekatan ini struktur sosial dipandang sebagai basis dari pengelompokan politik, dimana tingkah laku politik seseorang, termasuk dalam menentukan pilihan politiknya, ditentukan oleh pengelompokan sosialnya yang pada umumnya didasarkan atas kelas sosial, agama, desa-kota, bahasa dan nasionalisme; (2) Sociological Approach. Pendekatan ini berpendapat bahwa tingkah laku politik seseorang dipengaruhi oleh identifikasi serta norma-norma yang dianut oleh satu 
kelompok;

(3) Ecological Approach. Pendekatan ini memandang faktor-faktor yang bersifat ekologis, seperti daerah, sangat menentukan tingkah laku politik seseorang; (4) Social Psychological Approach. Dalam pendekatan ini tingkah laku dan keputusan politik seseorang sangat dipengaruhi oleh interaksi antara faktor internal, seperti sistem kepercayaan, dan faktor eksternal, seperti pengalaman politik. Pendekatan ini memandang bahwa tingkah laku dan kepercayaan individu menentukan dan membentuk norma-norma kelompok; dan (5) Rational Choice Approach. Pendekatan ini memandang bahwa semakin modernnya serta makin tinggi tingkat pendidikan masyarakat, maka masyarakat akan selalu memperhitungkan keuntungan dan kerugian yang akan diperoleh bila melakukan satu tindakan politik.

Gagasan tentang klientelisme bukan sebuah gagasan yang baru dalam kajian-kajian ilmu politik terutama yang membahas fenomena relasi dan pola kekuasaan dalam perpolitikan di negara-negara berkembang (Hanif, 2009). Menurut Schmidt yang dikutip oleh Erman (2007), konsep klientelisme dielaborasi oleh ilmuwan antropologi dan kemudian ilmuwan sosiologi untuk menjelaskan hubungan-hubungan sosial yang hirarkis yang telah lama ada dalam masyarakat petani. Kemudian konsep ini digunakan ilmuwan politik untuk menjelaskan definisi politik 'who gets what' dalam masyarakat.
Awalnya konsep klientelisme digunakan untuk menjelaskan politik tingkat desa, namun berkembang untuk menjelaskan seluruh sistem politik di tingkat nasional. Menurut Migdal yang dikutip Erman (2007), klientelisme cenderung subur di lingkungan politik yang tidak aman dan merupakan bagian dari 'politics of survival' baik bagi patron maupun klien, baik di desa maupun di kota.

Klientelisme didefinisikan sebagai transaksi antara politisi dan warga dimana terdapat imbalan materi atas dukungan politik dalam pemilu (Wantchekon, 2003). Eisenstadt dan Roniger (1980) mendefinisikan klientelisme sebagai bentuk personal, pertukaran yang bersifat dyadic dan didasarkan pada perasaan wajib serta adanya ketidakseimbangan kekuasaan diantara mereka yang terlibat. Sedangkan James Scott dalam Muno (2010) mendefinisikan klientelisme sebagai mekanisme persahabatan dimana individu dengan status sosial ekonomi yang tinggi (patron) menggunakan pengaruh dan sumberdayanya dengan memberikan perlindungan atau keuntungan atau keduanya kepada orang yang lebih rendah statusnya (klien) yang sebagai bagian dari patron memberikan dukungan dan jasa kepada patron. Jika patrimonialisme merujuk pada sistem pemerintahan yang berdasarkan kekeluargaan serta hubungan patron-klien, maka klientelisme merujuk pada ikatan-ikatan personal antara patron dan kliennya. Ikatan ini lebih didasarkan pada pengambilan 
keuntungan materi antara dua belah pihak (Erman, 2007).

Menurut Piattoni dalam Hopkins (2006), definisi yang ada merefleksikan konsep dasar klientelisme sebagai penjelas hubungan hirarkis patron-klien dalam masyarakat perdesaan yang tradisional. Klientelisme dipandang sebagai sebuah cara mendeskripsikan pola yang tidak seimbang dan karakteristik hirarkis masyarakat feodal, dimana patron dan klien diikat oleh perasaan yang kuat akan kewajiban dan tugas dalam suatu hubungan jangka panjang.

Dalam perkembangannya praktik klientelisme sendiri mengalami transformasi sesuai dengan transformasi sosial yang berlangsung di masyarakat. Jika melihat pada definisi yang dikemukakan Piattoni menunjukkan apa yang disebut Tarrow (1967) sebagai 'notables clientelism' atau Weingrod (1968) sebagai 'old clientelism'. Adanya perubahan sosioekonomi dimana terjadi pergerakan mobilitas sosial dan urbanisasi, tingkat pendidikan yang tinggi, perubahan dari masyarakat agraris ke masyarakat industri, serta menurunnya pengaruh elite tradisional perdesaan, membawa pengaruh pada hubungan klientelisme tersebut yang kemudian memunculkan istilah 'new clientelisme' (Hopkins, 2006).

Terkait dengan pertukaran, politisi dan partai politik dapat memperoleh dukungan melalui pemberian secara langsung hadiah atau kebijakan-kebijakan tertentu. Allen (2012) menyebut pertukaran barang itu sebagai clientelistic goods merujuk pada barang-barang material atau kebijakankebijakan yang diberikan oleh patron untuk klien sebagai bentuk pertukaran dukungan politik. Dalam hal clientelistic goods, incumbent lebih memiliki keleluasaan dibandingkan dengan lawannya. Incumbent memiliki sejumlah diskresi terhadap kebijakan mengenai sumberdaya yang dimiliki oleh pemerintah (Wantchekon, 2003).

Menurut Muno (2010) terdapat sejumlah karakteristik untuk mengidentifikasi konsep klientelisme, yaitu: pertama, hubungan bersifat dyadic. Di dalam klientelisme terdapat hubungan personal antara patron dan perantara (broker) di satu sisi dan perantara dengan klien di sisi yang lain. Patron dan klien tidak mengenal secara personal. Hubungan yang ada pada awalnya bersifat dyadic dan berkembang menjadi triad. Namun intinya tetap bersifat dyadic, karena perantara merupakan klien bagi patron, sedangkan perantara juga dapat berperan sebagai patron bagi klien. Kedua, hubungan bersifat asimetris. Dalam klientelisme hubungan patron dan klien selalu asimetris. Patron tidak hanya menguasai distribusi informasi, namun juga menguasai distribusi sumberdaya, kekuasaan, uang, barang, dan sebagainya. Kondisi ini mungkin terjadi di daerah perdesaan. Ketiga, hubungan bersifat pribadi dan tahan lama. Dalam klientelisme hubungan tidak bersifat sporadis, spontan serta hanya bersifat bisnis saja, melainkan saling mengenal dan percaya satu sama lain. 
Terkadang hubungan itu bersifat turun temurun. Kondisi tersebut merupakan ciri klientelisme klasik. Sedangkan klientelisme modern tidak perlu menyiratkan adanya turun temurun, tetapi tetap ada unsur personalitas dan tahan lama. Keempat, hubungan bersifat timbal balik. Pertukaran barang-barang yang berbentuk materi maupun nonmateri yang bersifat timbal balik merupakan inti dari klientelisme. Patron mengontrol sumberdaya dan memberikannya kepada kliennya. Klien menerima dan menggunakan sumberdaya tersebut dan menukarkannya dengan sumberdaya yang dimiliki. Pertukaran itu tidak harus segera diberikan, namun dapat dalam waktu tertentu. Dan kelima, hubungan bersifat sukarela. Dalam klientelisme mekanisme dukungan tidak dengan kekerasan.

\section{Metodologi}

Penelitian ini menggunakan metode kuantitatif karena tujuan dari penelitian ini adalah untuk mengetahui hubungan antar variabel dan merupakan penelitian mengenai perilaku memilih. Metode kuantitatif dinamakan juga metode tradisional atau metode positivistik. Metode ini menggunakan data penelitian berupa angka-angka dan analisis menggunakan statistik (Sugiyono, 2010).

Penelitian tentang perilaku memilih umumnya merupakan riset kuantitatif. Riset politik kuantitatif adalah dengan menggunakan pengukuran dalam analisis perilaku atau sikap (Harrison, 2009).
Dalam penelitian ini populasi adalah pemilih yang menggunakan hak pilihnya dalam Pilkada Kabupaten Bekasi Tahun 2012. Berdasarkan latar belakang masalah penelitian, maka lokasi penelitian hanya pada Kecamatan Sukatani. Langkah berikutnya adalah menentukan sampel responden pemilih yang berada di Kecamatan Sukatani tersebut. Berdasarkan data KPU (2012) jumlah pemilih di Kecamatan Sukatani sebanyak 54.235 orang. Untuk menentukan besar sampel dan margin of error digunakan rumus Slovin dengan asumsi bahwa populasi berdistribusi normal. Dengan demikian, dalam penelitian ini dengan jumlah anggota populasi sebanyak 54.235 orang diperoleh sampel penelitian sebanyak 100 orang dengan margin of error sebesar $10 \%$ dan tingkat kepercayaan sebesar $95 \%$.

Pada penelitian teknik pengumpulan sampel dengan cara simple random sampling. Penggunaan teknik ini dilakukan secara acak tanpa memperhatikan strata yang ada dalam populasi serta dikarenakan populasi yang akan diteliti dianggap memiliki sifat homogen (Sugiyono, 2010). Sehingga perbedaan sifat populasi menjadi tidak penting. Penggunaan metode random atau acak bertujuan agar setiap anggota semesta memiliki probabilitas

Tabel 1. Chi-Square Tests Pemberian Uang Seb elum Pilkada

\begin{tabular}{|c|c|c|c|}
\hline & Value & $\mathrm{df}$ & Asymp. Sig. (2-sided) \\
\hline Pearson Chi-Square & $2.975^{\mathrm{a}}$ & 4 & .562 \\
\hline Likelihood Ratio & 3.718 & 4 & .446 \\
\hline L inear-by-Linear & إ 0 & & 116 \\
\hline Association & 2.467 & 1 & .116 \\
\hline $\mathrm{N}$ of Valid Cases & 100 & & \\
\hline
\end{tabular}

a. 4 cells $(44.4 \%)$ have expected count less than 5 . The minimum expected count is .63 . 
yang sama besar untuk dipilih (Kerlinger, 2006).

Berikutnya penarikan sampel pemilih di kecamatan penelitian. Jumlah desa di Kecamatan Sukatani sebanyak 7 desa, maka penarikan sampel pemilih dilakukan berdasarkan proporsi jumlah penduduk di setiap desa pada kecamatan penelitian sehingga total diperoleh 100 orang responden. Data yang diperoleh dianalisis dengan menggunakan metode kualitatif dan kuantitatif. Teknik analisis kualitatif ditujukan untuk memberikan penjelasan terhadap permasalahan yang diajukan dalam pertanyaan penelitian (research question). Sedangkan teknik analisis kuantitatif ditujukan untuk menafsirkan seberapa kuat pengaruh antar variabel yang disusun dalam model analisis. Semua data diolah dengan menggunakan program komputer SPSS 16.0 for windows.

Untuk teknik analisis data kuantitatif, maka digunakan dua cara, yaitu:

a. Tabulasi silang, digunakan untuk menganalisis ada tidaknya pengaruh antar variabel yang diteliti dengan melihat persentase antar variabel, yaitu antara variabel bebas $(\mathrm{X})$ dan variabel terikat (Y).

b. Penghitungan koefisien korelasi sederhana (parsial) dengan data nominal diuji dengan analisis statistik chi square. Penggunaan metode ini dimaksudkan untuk mengetahui kuat tidaknya pengaruh antara setiap variabel bebas (X) dan variabel terikat $(\mathrm{Y})$.

Teknik pengumpulan data primer dilakukan dengan kuesioner, dimana responden mengisi sejumlah pertanyaan penelitian. Untuk data sekunder, teknik pengumpulan data menggunakan sumber yang berasal dari buku, jurnal, laporan penelitian, dokumen, dan sumber tertulis lainnya yang berhubungan dengan penelitian ini.

\begin{tabular}{|c|c|c|c|}
\hline & Value & $\mathrm{df}$ & Asymp. Sig. (2-sided) \\
\hline Pearson Chi-Square & $.281^{\mathrm{a}}$ & 2 & .869 \\
\hline Likelihood Ratio & .485 & 2 & .785 \\
\hline L in ear-by-Linear & 036 & & 850 \\
\hline Association & & & \\
\hline $\mathrm{N}$ of Valid Cases & 100 & & \\
\hline
\end{tabular}

Kuesioner yang dipergunakan dalam penelitian ini merupakan kuesioner berbentuk skala. Jenis skala yang dipergunakan adalah skala Likert. Menurut Hadjar yang dikutip Tukiran dan Hidayati (2012), skala Likert digunakan untuk mengukur sikap.

\section{Temuan dan Diskusi}

Tujuan penelitian ini adalah untuk mengetahui pengaruh faktor klientelisme terhadap perilaku memilih masyarakat Sukatani pada Pilkada Kabupaten Bekasi tahun 2012. Untuk menganalisis pengaruh

Tabel 3. Chi-Square Tests Ajakan Tim Sukses Kandidat

\begin{tabular}{|c|c|c|c|}
\hline & Value & $\mathrm{df}$ & Asymp. Sig. (2-sided) \\
\hline Pearson Chi-Square & $12.785^{\mathrm{a}}$ & 4 & .012 \\
\hline Likelihood Ratio & 12.078 & 4 & .017 \\
\hline Linear-by-L inear & 5.292 & 1 & 021 \\
\hline Association & & & \\
\hline $\mathrm{N}$ of Valid Cases & 100 & & \\
\hline
\end{tabular}

count is .07 .

tersebut digunakan teknik analisis data chi square. Pada pelaksanaan penelitian terdapat 
sejumlah kendala, terutama terkait dengan responden. Responden yang dipilih secara acak berdasarkan Daftar Pemilih Tetap (DPT) Pilkada Kabupaten Bekasi tahun 2012 banyak mengalami perubahan, seperti sudah tidak bertempat tinggal di lokasi yang ada, meninggal, dan sebagainya. Jarak waktu penelitian yang cukup lama merupakan tantangan tersendiri ketika responden ditanyakan mengenai sejumlah hal.

Karakteristik responden dalam penelitian ini didasarkan pada jenis kelamin,

\begin{tabular}{|c|c|c|c|}
\hline & Value & $\mathrm{df}$ & Asymp. Sig. (2-sided) \\
\hline Pearson Chi-Square & $2.856^{\mathrm{a}}$ & 4 & .582 \\
\hline Likelihood Ratio & 3.887 & 4 & .422 \\
\hline Linear-by-Linear & & & \\
\hline Association & & & .528 \\
\hline $\mathrm{N}$ of Valid Cases & 100 & & \\
\hline
\end{tabular}

a. 6 cells $(66.7 \%)$ have expected count less than 5 . The minimum expected count is 21 .

umur, status perkawinan, agama, tingkat pendidikan, tingkat penghasilan, dan jenis pekerjaan,. Menurut Duverger (2007), faktor fisikal dan nonfisikal memiliki pengaruh terhadap perilaku pemilih. Dalam konteks penelitian ini, kedua faktor tersebut terbagi menjadi elemen kependudukan, elemen perekonomian, elemen etnisitas, elemen pendidikan, dan elemen agama.

Dalam penelitian ini, karakteristik responden berdasarkan jenis kelamin adalah dari 100 orang responden $64 \%$ berjenis kelamin laki-laki serta $36 \%$ berjenis kelamin perempuan. Sedangkan dari segi usia, responden yang berada pada kategori rentang usia 36-50 tahun sebanyak 44\%. Berikutnya adalah responden pada rentang usia 17-35 tahun sebanyak $42 \%$. Sedangkan yang paling sedikit berada pada usia di atas 50 tahun yaitu sebanyak 12 orang atau sebesar $14 \%$.

Adapun karakteristik responden berdasarkan status perkawinan diperoleh hasil sebanyak $60 \%$ berstatus menikah. Sedangkan yang belum menikah sebanyak $30 \%$ dan yang berstatus duda/janda sebanyak $10 \%$. Berdasarkan tingkat pendidikan responden diperoleh hasil tingkat pendidikan responden paling banyak adalah SMA/sederajat sebesar 53\%. Disusul responden berpendidikan SMP/sederajat sebesar $14 \%$, pendidikan SD sebesar $13 \%$. Sedangkan yang berpendidikan tinggi, yaitu yang lulus program diploma dan

Tabel 6. Chi-Square Tests Ajakan Kelompok Profesional

\begin{tabular}{|c|c|c|c|}
\hline & Value & $\mathrm{df}$ & Asymp. Sig. (2-sided) \\
\hline Pearson Chi-Square & $3.836^{\circ}$ & 4 & .429 \\
\hline Likelihood Ratio & 6.244 & 4 & .182 \\
\hline Linear-by-Linear & & & \\
\hline Association & 312 & 1 & $.37 \pi$ \\
\hline N of Valid Cases & 100 & & \\
\hline
\end{tabular}
count is 21 .

sarjana masing-masing sebesar 7\% dan $9 \%$. Adapun yang tidak tamat SD sebesar 4\%.

Karakteristik responden berdasarkan tingkat penghasilan diperoleh hasil tingkat penghasilan responden terbesar berada pada rentang Rp 1.000.001 - 2.000.000 dan di atas sama dengan Rp 2.000.001 yaitu masingmasing sebesar 33\%. Disusul tingkat penghasilan Rp 500.001 - 1.000 .000 sebesar 19\%. Sedangkan yang paling sedikit adalah mereka yang berpenghasilan kurang dari $\mathrm{Rp}$ 250.000 sebesar $5 \%$. 
Tabel 5. Chi-Square Tests Ajakan Pejabat In formal

\begin{tabular}{|c|c|c|c|}
\hline & Value & df & Asymp. Sig. (2-sided) \\
\hline Pearson Chi-Square & $8.332^{2}$ & 4 & .080 \\
\hline Likelihood Ratio & 8.798 & 4 & .066 \\
\hline Linear-by-Linear & & & \\
\hline Association & 5.005 & 1 & .010 \\
\hline $\mathrm{N}$ of Valid Cases & 100 & & \\
\hline
\end{tabular}

a. 4 cells $(44.4 \%)$ have expected count less than 5 . The minimum expected count is 21 .

Karakteristik responden berdasarkan pekerjaan terbanyak adalah wiraswasta/ pedagang sebesar 34\%. Disusul responden yang bekerja sebagai pegawai industri atau buruh pabrik sebesar $31 \%$. Responden yang bekerja sebagai pegawai swasta sebesar $15 \%$ serta yang menjadi petani sebesar $13 \%$. Adapun responden yang bekerja sebagai mahasiswa dan PNS/BUMN masing-masing sebesar 5\% dan 2\%. Sedangkan karakteristik pekerjaan sebagai nelayan dan anggota TNI/POLRI tidak terwakili.

Adapun karakteristik responden berdasarkan agama paling banyak adalah Islam sebesar 97\%. Disusul agama Kristen Katolik dan Kristen Protestan masing-masing sebesar 2\% dan 1\%. Kondisi ini tidak mengherankan mengingat mayoritas penduduk Kabupaten Bekasi beragama Islam. Bahkan di Kabupaten Bekasi terdapat tokoh Islam sekaligus pejuang kemerdekaan, K.H. Noer Ali.

Dalam penelitian ini terdapat beberapa temuan mengenai perilaku pemilih masyarakat Kecamatan Sukatani Kabupaten Bekasi dalam Pilkada Kabupaten Bekasi tahun 2012. Dalam hal mengetahui adanya pilkada dan ikut memberikan suara, masyarakat Kecamatan Sukatani Kabupaten Bekasi mengetahui dan aktif memberikan suaranya. Sebanyak $96 \%$ responden mengetahui adanya pilkada dan hanya $4 \%$ yang tidak mengetahuinya. Namun demikian, meski ada masyarakat yang tidak mengetahui akan adanya pilkada, tetapi ketika pelaksanaan pilkada mereka semuanya berpartisipasi aktif dalam mencoblos.

Adapun pasangan kandidat yang paling banyak dipilih adalah pasangan kandidat Neneng Hasanah Yasin-Rohim Mintareja yaitu sebanyak 67\%. Disusul dengan pasangan kandidat Sa'duddin-Jamal Lulail Yunus sebanyak 26\% dan terakhir pasangan kandidat Darip Mulyana-Jejen Sayuti sebanyak $7 \%$.

Selanjutnya mengenai dasar pertimbangan memberikan suara pada pemilu sebagian besar responden menyatakan melihat iklan TV/radio/dan sebagainya, yaitu sebanyak $31 \%$. Ketika ditanyakan pengaruh jenis kelamin sebagai dasar pertimbangan dalam memilih, diperoleh hasil sebanyak $89 \%$ responden menyatakan jenis kelamin tidak berpengaruh serta sebanyak $11 \%$ mendasarkan pertimbangan pada jenis kelamin. Dari $89 \%$ pemilih yang tidak mendasarkan pilihannya karena faktor jenis kelamin, 33 orang diantaranya adalah perempuan. Seperti diketahui bahwa kandidat yang memenangi Pilkada Kabupaten Bekasi tahun 2012 adalah seorang perempuan. Dengan demikian tampak bahwa pemilih perempuan tidak memandang faktor jenis kelamin dalam mendasarkan pilihannya. 
Pada saat ditanyakan mengenai popularitas kandidat, sebanyak $52 \%$ responden menyatakan popularitas tidak mempengaruhi dalam memilih. Sedangkan sebanyak $47 \%$ responden masih mendasarkan pilihan pada popularitas kandidat dan hanya $1 \%$ yang menyatakan tidak tahu.

Adapun bagaimana pengaruh pemberian uang sebelum pelaksanaan pilkada dengan perilaku memilih masyarakat diperoleh hasil sebanyak $70 \%$ responden menyatakan tidak menerima pemberian uang sebelum pelaksanaan pilkada, sebanyak $21 \%$ menyatakan menerima, dan $9 \%$ menyatakan tidak tahu. Hal ini menunjukkan bahwa pada dasarnya proses pemberian uang untuk memilih salah satu kandidat sudah dilakukan sebelum pelaksanaan pilkada.

Untuk mendapatkan kesimpulan apakah hipotesis ditolak atau diterima dapat diperhatikan output Chi-Square Tests. Hipotesis yang diajukan adalah: $\mathrm{H}_{\mathrm{o}}=$ tidak ada perbedaan perilaku pemilih karena pengaruh klientelisme didasarkan pada pemberian uang. Sedangkan $\mathrm{H}_{1}=$ ada perbedaan perilaku pemilih karena pengaruh klientelisme didasarkan pada pemberian uang.

Hasil perhitungan diperoleh hasil Asymp. Sig. (2-sided) sebesar 0,562 sebagaimana hasil pada Tabel 1. Karena Asymp. Sig. (2-sided) lebih besar dari 0,05 maka $\mathrm{H}_{\mathrm{o}}$ diterima. Dari temuan tersebut dapat dikatakan bahwa tidak ada perbedaan perilaku memilih masyarakat Kecamatan Sukatani
Kabupaten Bekasi tahun 2012 berdasarkan pemberian uang.

Adapun pengaruh popularitas orang tua kandidat terhadap perilaku memilih masyarakat menunjukkan sebanyak 97\% responden tidak mendasarkan pilihannya karena popularitas orang tua kandidat. Seperti diketahui bahwa orang tua kandidat Bupati Bekasi Neneng Hasanah Yasin, yang memenangkan Pilkada Kabupaten Bekasi tahun 2012 memiliki orang tua H. Yasin yang terkenal sebagai tuan tanah dan juragan beras di Kabupaten Bekasi. Diperkuat lagi dengan adanya dugaan keterlibatan orang tua Neneng Hasanah Yasin dalam proses pemenangan pilkada anaknya. Meskipun hasil keputusan Mahkamah Konstitusi menyatakan tidak adanya bukti keterlibatan tersebut, paling tidak popularitas orang tua Neneng Hasanah Yasin turut mempengaruhi kemenangan putrinya. Sedangkan sebanyak 3\% responden menyatakan tidak tahu dasar pemberian suara tersebut.

Untuk mendapatkan kesimpulan apakah hipotesis ditolak atau diterima dapat diperhatikan output Chi-Square Tests. Hipotesis yang diajukan adalah: $\mathrm{H}_{\mathrm{o}}=$ tidak ada perbedaan perilaku pemilih karena pengaruh klientelisme didasarkan pada popularitas orang tua. Sedangkan $\mathrm{H}_{1}=$ ada perbedaan perilaku pemilih karena pengaruh klientelisme didasarkan pada popularitas orang tua.

Berdasarkan hasil hitung chi square sebesar 0,869 dan karena Asymp. Sig. (2- 
sided) lebih besar dari 0,05 , maka $\mathrm{H}_{\mathrm{o}}$ diterima sebagaimana hasil pada Tabel 2. Dari temuan tersebut dapat dikatakan bahwa tidak ada perbedaan perilaku memilih masyarakat Kecamatan Sukatani Kabupaten Bekasi tahun 2012 berdasarkan popularitas orang tua kandidat.

Sedangkan pengaruh ajakan tim sukses kandidat terhadap perilaku memilih masyarakat menunjukkan sebanyak $82 \%$ menyatakan tidak dipengaruhi ajakan tim sukses kandidat. Sedangkan sebanyak 17\% responden menyatakan diajak oleh tim sukses kandidat dan $1 \%$ menyatakan tidak tahu. Seperti diketahui bahwa tim sukses kandidat turut memegang peranan dalam pemenangan kandidat. Tim sukses ini dibentuk dari relawan-relawan pendukung kandidat serta tidak memiliki jabatan formal maupun informal di masyarakat.

Untuk mendapatkan kesimpulan apakah hipotesis ditolak atau diterima dapat diperhatikan output Chi-Square Tests. Hipotesis yang diajukan adalah: $\mathrm{H}_{\mathrm{o}}=$ tidak ada perbedaan perilaku pemilih karena pengaruh klientelisme didasarkan pada ajakan tim sukses kandidat. Sedangkan $\mathrm{H}_{1}=$ ada perbedaan perilaku pemilih karena pengaruh klientelisme didasarkan pada ajakan tim sukses kandidat.

Berdasarkan hasil hitung chi square untuk mengetahui pengaruh ajakan tim sukses kandidat diperoleh hasil 0,012 dan karena Asymp. Sig. (2-sided) lebih kecil dari 0,05, maka $\mathrm{H}_{\mathrm{o}}$ tidak diterima sebagaimana hasil pada Tabel 3. Dari temuan tersebut dapat dikatakan bahwa ada perbedaan perilaku memilih masyarakat Kecamatan Sukatani Kabupaten Bekasi tahun 2012 berdasarkan ajakan tim sukses kandidat.

Adapun pengaruh ajakan pejabat formal terhadap perilaku memilih masyarakat menunjukkan sebanyak $93 \%$ responden menyatakan tidak mendasarkan pilihannya karena ajakan pejabat formal. Pejabat formal di masyarakat adalah bupati, camat, lurah atau kepala desa. Apalagi dalam Pilkada Kabupaten Bekasi tahun 2012 ini terdapat pasangan petahana, yaitu Sa'duddin sebagai Bupati Bekasi yang berpasangan dengan Jamal Luail Yunus serta Darip Mulyana sebagai Wakil Bupati Bekasi yang berpasangan dengan Jejen Sayuti. Dalam konteks ini jabatan formal mereka dapat memberikan instruksi kepada aparatur di bawahnya untuk memilih yang bersangkutan.

Untuk mendapatkan kesimpulan apakah hipotesis ditolak atau diterima dapat diperhatikan output Chi-Square Tests. Hipotesis yang diajukan adalah: $\mathrm{H}_{\mathrm{o}}=$ tidak ada perbedaan perilaku pemilih karena pengaruh klientelisme didasarkan pada ajakan pejabat formal. Sedangkan $\mathrm{H}_{1}=$ ada perbedaan perilaku pemilih karena pengaruh klientelisme didasarkan pada ajakan pejabat formal.

Berdasarkan hasil hitung chi square untuk mengetahui pengaruh ajakan pejabat formal terhadap perilaku memilih masyarakat diperoleh nilai sebesar 0,582 dan karena 
Asymp. Sig. (2-sided) lebih besar dari 0,05, maka $\mathrm{H}_{\mathrm{o}}$ diterima sebagaimana hasil pada Tabel 4. Dari temuan tersebut dapat dikatakan bahwa tidak ada perbedaan perilaku memilih masyarakat Kecamatan Sukatani Kabupaten Bekasi tahun 2012 berdasarkan ajakan pejabat formal.

Terkait dengan pengaruh ajakan pejabat informal terhadap perilaku memilih masyarakat sebanyak $76 \%$ responden menyatakan tidak terpengaruh ajakan pejabat informal. Sedangkan sebanyak $21 \%$ responden menyatakan dipengaruhi oleh ajakan pejabat informal dan hanya $3 \%$ menyatakan tidak tahu. Pejabat informal dalam masyarakat seperti kiai, ulama, ustadz, pendeta, tokoh masyarakat, tokoh pemuda, dan sebagainya.

Untuk mendapatkan kesimpulan apakah hipotesis ditolak atau diterima dapat diperhatikan output Chi-Square Tests. Hipotesis yang diajukan adalah: $\mathrm{H}_{\mathrm{o}}=$ tidak ada perbedaan perilaku pemilih karena pengaruh klientelisme didasarkan pada ajakan pejabat informal. Sedangkan $\mathrm{H}_{1}=$ ada perbedaan perilaku pemilih karena pengaruh klientelisme didasarkan pada ajakan pejabat informal.

Berdasarkan hasil hitung chi square untuk mengetahui pengaruh ajakan pejabat informal terhadap perilaku memilih masyarakat diperoleh nilai sebesar 0,080 dan karena Asymp. Sig. (2-sided) lebih besar dari 0,05 , maka $H_{o}$ diterima sebagaimana hasil pada Tabel 5. Dari temuan tersebut dapat dikatakan bahwa tidak ada perbedaan perilaku memilih masyarakat Kecamatan Sukatani Kabupaten Bekasi tahun 2012 berdasarkan ajakan pejabat informal.

Sedangkan pengaruh ajakan kelompok professional seperti kelompok tani, kelompok nelayan, koperasi, organisasi buruh, dan sebagainya, sebanyak $75 \%$ responden menyatakan tidak terpengaruh oleh ajakan kelompok professional, sebanyak 22\% responden menyatakan dipengaruhi ajakan kelompok professional tersebut, dan sebanyak $3 \%$ responden menyatakan tidak tahu. Demikian pula ketika ditanyakan apakah dasar pemberian suara karena hutang budi kepada kandidat dan orang tua kandidat, seluruh jawaban responden sebesar $100 \%$ menyatakan tidak. Hal ini menunjukkan bahwa responden memiliki sikap yang otonom dalam pemberian suara.

Untuk mendapatkan kesimpulan apakah hipotesis ditolak atau diterima dapat diperhatikan output Chi-Square Tests. Hipotesis yang diajukan adalah: $\mathrm{H}_{\mathrm{o}}=$ tidak ada perbedaan perilaku pemilih karena pengaruh klientelisme didasarkan pada ajakan kelompok professional. Sedangkan $\mathrm{H}_{1}=$ ada perbedaan perilaku pemilih karena pengaruh klientelisme didasarkan pada ajakan kelompok professional.

Analisis terhadap pengaruh ajakan kelompok professional terhadap perilaku memilih masyarakat di Kecamatan Sukatani sebagaimana hasil pada Tabel 6. Berdasarkan hasil hitung chi square sebesar 0,429 dan 
karena Asymp. Sig. (2-sided) lebih besar dari 0,05 maka $\mathrm{H}_{\mathrm{o}}$ diterima. Dari temuan tersebut dapat dikatakan bahwa tidak ada perbedaan perilaku memilih masyarakat Kecamatan Sukatani Kabupaten Bekasi tahun 2012 berdasarkan ajakan kelompok professional.

\section{Kesimpulan}

Terdapat beberapa temuan mengenai perilaku pemilih masyarakat Kecamatan Sukatani Kabupaten Bekasi dalam Pilkada Kabupaten Bekasi tahun 2012. Terkait dengan klientelisme, bahwa faktor pemberian uang sebelum pelaksanaan pilkada, popularitas orang tua, ajakan tim sukses kandidat, ajakan pejabat formal, ajakan pejabat informal dan ajakan kelompok professional tidak berpengaruh terhadap perilaku memilih masyarakat Kecamatan Sukatani Kabupaten Bekasi. Namun, ketika dianalisis menggunakan chi square, terdapat perbedaan di antara faktor-faktor tersebut. Faktor pemberian uang, popularitas orang tua, ajakan pejabat formal, ajakan pejabat informal, dan ajakan kelompok professional tidak ada perbedaan perilaku memilih tersebut. Sebaliknya ajakan tim sukses kandidat terdapat perbedaan perilaku memilih tersebut.

Seperti telah dijelaskan pada bagian awal bahwa penelitian ini memiliki keterbatasan, baik dari segi variabel pengaruh, variabel kontrol, metode yang digunakan, teknik analisa data, jumlah sampel, dan wilayah penelitian. Oleh sebab itu, untuk lebih memperkaya kajian mengenai klientelisme dan pilkada pada penelitian selanjutnya dapat dilakukan dengan menambahkan dengan variabel pengaruh lainnya, seperti variabel identifikasi partai, variabel identifikasi kandidat, dan sebagainya, serta menggunakan metode tertentu yang dapat menjelaskan mengenai klientelisme. Dalam hal analisa data dapat digunakan analisa regresi untuk dapat memprediksi terjadinya klientelisme.

\section{Daftar Pustaka}

Allen, N. W. (2015). Clientelism and the personal vote in Indonesia. Electoral Studies, 37, 73-85.

Antunes, R. (2010). Theoretical models of voting behaviour. Exedra, 4, 145-170.

Asfar, M. (2005). Pilkada dan Penciptaan Pemerintahan yang Representatif. dalam Ahmad Nadir.

Duverger, M., Dhakidae, D., \& Alfian. (2000). Sosiologi politik. Rajagrafindo Persada (Rajawali Pers): Yayasan Ilmu Ilmu Sosial (YIIS).

Eisenstadt, S. N., \& Roniger, L. (1980). Patron-client relations as a model of structuring social exchange. Comparative studies in Society and History, 22(01), 42-77.

Erman, E. (2007). Indikasi Patrimonialisme dan Klientalisme dalam Proses Pilkada" dalam Syarif Hidayat \& Hari Susanto (eds) Bisnis dan Politik di Tingkat Lokal: Pengusaha, Penguasa, dan Penyelenggaraan Pemerintahan Daerah pasca Pilkada. Jakarta. 
Hanif, H. (2009). Politik Klientelisme Baru dan Dilema Demokratisasi di Indonesia. Jurnal Ilmu Sosial dan Ilmu Politik, 12(3), 327-351.

Harrison, L. (2007). Metodologi Penelitian Politik. Jakarta: Kencana.

Hopkin, J. (2006). Clientelism and party politics (pp. 406-412). Sage.

Hopkin, J. (2006, August). Conceptualizing political clientelism: Political exchange and democratic theory. In APSA Annual Meeting Philadelphia, USA.

http://humaskabbekasi.wordpress.com/profilkabupaten-bekasi/ diakses tanggal 18 Februari 2013.

http://www.republika.co.id/berita/regional/jab odetabek/12/03/20/m16y3q-kalahpilkada-dahsyay-saja-ajukan-gugatanke-mk, diakses tanggal 30 Mei 2012.

Imawan, R. Dinamika Pemilih dalam Pemilu 1992" dalam M. Sudibjo (Penyunting). 1995. Pemilihan Umum 1992: Suatu Evaluasi.

Keputusan Mahkamah Konstitusi Nomor 9/PHPU.D-X/2012 tanggal 10 April 2012.

Kerlinger Fred, N. (2006). Asas-Asas Penelitian Behavioral, edisiketiga.
Muno, W. (2010, August). Conceptualizing and measuring clientelism. In Paper to be presented at the workshop on Neopatrimonialism in Various World Regions, GIGA German Institute of Global and Area Studies, Hamburg.

Nuraina, Aos Kuswandi, Ainur Rofieq, Atie Dermawati. (2008). Statistik dan Analisis Gender Kabupaten Bekasi Tahun 2008, Bekasi: Badan Pemberdayaan Masyarakat Kabupaten Bekasi dan Pusat Studi Wanita Universitas Islam “45” Bekasi.

Ghozali, I. (2011). Metode Penelitian Kuantitatif, Kualitatif dan R \& D. Bandung, Alfabeta.

Surbakti, R. (1992). Memahami ilmu politik. Grasindo.

Taniredja, T., \& Mustafidah, H. (2011). Penelitian Kuantitatif (sebuah pengantar), Bandung: Alfabeta.

Wantchekon, L. (2003). Clientelism and voting behavior: Evidence from a field experiment in Benin. World politics, 55(03), 399-422. 